\title{
A co-regulatory approach to stay safe online: Reporting inappropriate contents with the MediaKids mobile app
}

\author{
Marta Poblet, ${ }^{1 *}$ Emma Teodoro ${ }^{\#}$, Jorge González-Conejero ${ }^{\#}$, Rebeca Valera ${ }^{\#}$, Pompeu \\ Casanovas $^{\#}$ \\ "RMIT University, Graduate School of Business and Law, GPO Box 2476 Melbourne VIC 3001 \\ Australia; e-mail: martapobletbalcell@rmit.edu.au \\ "Autonomous University of Barcelona, Institute of Law and Technology, Faculty of Law, Building \\ B; 08193 Bellaterra, Spain
}

\section{Acknowledgments}

This work was supported by the Obra Social La Caixa under Grant RecerCaixa2012; Spanish Ministry of Economy and Competitiveness (MINECO) under Grant DER2012-39492-C02-01.

\begin{abstract}
The convergence of mobile technologies, media, and the Internet is transforming the way that digital content is produced, distributed, and consumed, especially among children and young adults. In Europe as in many other areas, minors are exposed to an ever-growing amount of digital content on mobile phones, tablets, or computer screens. Increasing exposure at an early age brings both new opportunities and risks. This paper reviews the current discussion about strategies that deal with inappropriate, harmful, and illegal content online and proposes a particular co-regulatory, technology-driven approach based on the active involvement of children, their families, and the educational system. The MediaKids project aims to test this coregulatory approach by developing a mobile application-the MediaKids app-within the broader context of an educational programme to raise awareness about online safety. The project seeks to involve children and young adults in defining the notion of "harmful content" and, ultimately, in the elaboration of the policies for the emergent digital public space.
\end{abstract}

\section{Keywords}

Children, young adults, mobile technologies, digital content, online safety, regulation

\section{Introduction}

In 2015, for the first time, the number of active mobile subscriptions has exceeded the total world population (GSMA Intelligence, 2015). In regard to mobile-broadband--the fastest growing market segment with continuous double-digit growth rates--the penetration reaches 32 percent

\footnotetext{
${ }^{1}$ Correspondence to: Marta Poblet, Graduate School of Business and Law, RMIT University, GPO Box 2476 Melbourne VIC 3001 Australia; e-mail: martapobletbalcell@rmit.edu.au
} 
globally and 84 percent in developing countries (ITU, 2014). The unprecedented convergence of mobile technologies-from basic phones to smartphones and tablets-geolocated data and crowdsourcing technologies is generating a geospatial revolution that redefines the notions of space, law, and data from a relational perspective (Casanovas and Poblet, 2008; Poblet, 2011; Casanovas, 2012; Poblet, 2013; Poblet et al., 2014). Space becomes relational as it not only refers to our position in geographical coordinates, but to the way we interact with our immediate context; as a result, data is not just our personal data but also includes the digital footprints we leave as we interact with our context. Similarly, law adopts a relational form: it comprises not just a set of legislative instruments, but also complex regulatory models that include soft law (standards, codes of conduct, best practices) and alternative dispute resolution mechanisms (negotiation, mediation, arbitration) tailored to the needs of users and communities.

The project MediaKids, developed by researchers at the Institute of Law and Technology of the Autonomous University of Barcelona explores these emerging trends. MediaKids is not simply conceived as an app but as a service that creates its own social ecosystem based on the cooperation between families (parents and siblings) and schools (peers and teachers) to produce educational and socialisation effects.

This paper considers the impact of the geospatial revolution on the consumption of digital media content by children and young adults. The use of mobile phones is now most common among ever younger age groups, who either have their own devices or access the ones available at home. The European Commission "Green Paper on Preparing for a Fully Converged Audiovisual World: Growth, Creation and Values" noted that "lines are blurring quickly between the familiar twentieth-century consumption patterns of linear broadcasting received by TV sets versus on-demand services delivered to computers" (2013, p. 3). Given that by 2016 , the majority of consumer internet traffic is expected to be video and, IP traffic is going to be channelled mainly through WI-FI and mobile devices (European Commission, 2013) the screens of both phones and tablets will consolidate as the primary outlets for digital media consumption. These trends bring both opportunities and risks that call for a new regulatory paradigm where the active participation of minors and their families is required to foster a critical attitude towards digital media.

The remaining sections of this paper are organised as follows: Section 2 sets the domain of study and the background for the MediaKids project. Section 3 provides an overview of regulatory tools and approaches to manage harmful or illegal digital media contents. In section 4 we present the MediaKids project and the MediaKids app as one of the research outcomes. Finally, Section 5 offers concluding remarks and suggests areas for future work.

\section{Background}


Literature on the uses of mobile technologies among children and youth is abundant and pluridisciplinary. Researchers in mobile communication studies, sociology of family and education, and social and developmental psychology are early contributors to this domain (e.g. Katz and Aakhus, 2002; Ling, 2004, 2007, 2008; Castells et al. 2007; Selwin, 2003; Williams and Williams, 2005). Most research is primarily based on country studies (e.g. Kasesniemi, 2003; Oksman and Rautiainen, 2003; Ito, 2005; Chen and Katz, 2009; Kaare et al., 2007; Plowman et al., 2010; Green et al., 2011, 2012, 2013; Hertlein, 2012; Jackson et al., 2012; Palmer et al., 2012; Plowman and McPake, 2013; McPake et al., 2013; Livingstone et al., 2014b; Livingstone et al., 2015). Other studies address specific groups within these ages, such as children with diabetes (Hirose et al., 2012; Toscos et al., 2012), asthma (Mosnaim et al., 2012) intellectual and developmental disabilities (Palmer et al., 2012; Hwang et al. 2014), complex communication needs (Light and McNaughton, 2012) and obesity (Woolford et al., 2012; Sharifi et al., 2013). In Europe, the most comprehensive studies have been produced by the EU projects, "EU Kids Online"2 and "Net Children Go Mobile", 3 which conducted a panEuropean survey of interviews over 33,000 children (as well as some of their parents and teachers) between 2010-2014.

The pan-European survey offers relevant data on the online behaviour of children and young people using the Internet: 60 percent of 9 to 16 year old users go online everyday or almost everyday; the most common activities are visiting social networking profiles (63 percent), watching video clips (59 percent), instant messaging (49 percent) and posting photos, music or videos (20 percent); the common location of Internet uses are at home (87 percent) and at school (63 percent); children access the Internet in their bedroom (49 percent) and 33 percent via a mobile phone or handheld device (Livingstone et al., 2014a). In Europe, 38 percent of 9-12 year olds and 77 percent of 13-16 year olds have a social network profile (Rizza and Pereira, 2013). In Australia, where 76 percent of 9-16 year-olds go online daily or almost daily, two thirds (65 percent) of them have their own social network profile, a little more than the EU 25 nation average of 59 percent (Green et al., 2013). In the US, where 95 percent of 12-17 years old use the Internet, 81 percent use some kind of social media (Pew Research, 2013).

The growing exposure to an Internet that is becoming more social and, at the same time, more "individualized, privatized, and mobile" (Rizza and Pereira, 2013) unavoidably points to both the risks and opportunities involved with an ever expanding offer of multimedia options. While parental concerns are usually represented in the public discourse in terms of "overexposure", "addiction" or even "toxicity", recent literature on digital media uses also argues that there is no "evidence from parents to support the notion that children's experiences with technology were having a detrimental effect on their behaviour, health, or learning" (Plowman and MacPake, 2013, p. 28). The literature also highlights positive effects in terms of education and socialisation (e.g Shuler, 2009; Strasburger et al., 2013; Granic et al., 2014; Rideout, 2014; Shapiro and Margolin, 2014; Vincent, 2015, Bell et al., 2015). In terms of family relationships, Padilla-Walker et al. have also found that "greater amounts of family cell phone use, coviewing

${ }^{2}$ www.Ise.ac.uk/media@Ise/research/EUKidsOnline/Home.aspx

${ }^{3}$ www.NetChildrenGoMobile.eu 
of TV and movies, and coplaying of videogames were associated with higher levels of family connection, at least from the adolescent perspective" (2012, p. 426); Livingstone et al. have observed that use of technology is "embedded into everyday family", including "intergenerational interactions around technology" (2015, p. 44); and Correa et al. conclude from their research that "children play a role in including their parents in the digital environment, particularly among women, people who are older (35 years old and above) and belong to lower socio-economic groups" (2015, p. 1).

If digital technologies offer these opportunities, then how do children, young adults, and their parents perceive the potential risks? The pan-European survey reports that, generally (but not for all countries) there is a positive association between opportunities and risks, and these may commonly consist of receiving nasty or hurtful messages ("cyberbullying"), potentially negative forms of user-generated content such as hate, pro-anorexic or self-harm content, receiving sexual messages ("sexting") or exposure to sexual images or pornography, among others (Livingstone et al., 2014a). The same survey also points out that 40 percent of parents whose child has seen sexual images online were not aware of this situation, and 56 percent of them did not know that their child had received nasty or hurtful messages online. When it comes to potential risks, though, parents put contact-related risks at the top of their concerns, while children refer to pornographic, violent, scary, or unwanted content-as their main concern (Livingstone et al., 2011).

In Australia, 30 percent of children reported that they have been bothered or upset by something online in the previous year, which represents two and a half times the European average (12 percent) and more than any of the 25 EU countries surveyed; 34 per cent of Australian 11-16 year olds have seen one or more type of potentially harmful user-generated content; as with Europe, Australian parents are also less likely to recognise that their children have been bothered online (16 percent of 30 percent) (Green et al., 2013).

In Spain, where 70 percent of 12 year olds own a mobile phone (INE, 2014), infants aged 2-3 years old access their parents mobile apps to draw, paint, play or watch videos (Canovas et al., 2014). As regards privacy issues, the same study notes that 71 percent of 11-14 year olds interviewed express concerns about the use of personal data by the applications they download, and 75 percent of minors have decided at least once not to download an application because of the potential threats to personal data. Additional survey data also reveals that: 5.4 percent of 11-12 year olds have chatted with unknown people (18 percent of 13-14 year olds); 2.4 percent of 11-12 year olds have been bothered online (8.4 percent of 13-14 year olds); 4.1 percent of 11-12 year olds have received sexually explicit messages or images on the phone (13.7 percent of 13-14 year olds).

Mobiles have become an "organic part" of children and young adults (Oksman and Rautiainen, 2003, p. 293) and, as such, they all have developed shared routines and behaviour patterns to address opportunities and risks. Analysing them as an integral part of a relational strategy to stay safe online is at the core to our multi-layered socio-legal perspective. 


\section{Strategies to address inappropriate digital contents}

As a result of the convergence of media and Information and Communications Technologies (ICTs), traditional leisure activities such as listening to music, watching films and television, and reading newspapers or books have changed. Consequently, the production, distribution, and consumption of digital content in the digital world has also changed. In this scenario, the protection of minors faces new challenges, especially in the online media environment.

There is no consensus on the concept of "harmful content" and what it includes, since it is culturally bounded (Lievens, 2007). In general terms we may define harmful content as that which is legal for adults to access but may harm vulnerable persons, particularly minors. The concept of harmful content deals with one's beliefs, preferences, and social and cultural traditions (Bonnici et al., 2005). Content that is pornographic or sexual, violent or aggressive, scary or gory and promotes drugs, racism, hatred, self-harm, suicide or anorexia are some examples of harmful content. In contrast, illegal content is that which the law prohibits. Examples of illegal content are child pornography or discriminatory content, among others.

The new challenges regarding harmful content are being addressed by policy makers and relevant stakeholders from the ICT sector. Over the past years, different regulatory instruments and actions such as legislative measures, self-regulation and co-regulation have been deployed. Yet, these instruments are not effective enough to ensure minors' protection in this convergent scenario, as they do not take into account the minor's views on harmful content. Likewise, regulatory instruments have not paid attention to the strategies that minors have adopted in practice toreduce exposure to undesirable content. In this scenario, parental responsibility continues to be the key factor that influences the protection of minors.

Our approach goes a step further to explore the potential benefits of engaging and empowering minors (and civil society at large) to protect themselves against harmful and illegal digital content, and to leverage mobile technologies as a practical tool to report on this type of content.

\subsection{Regulatory instruments}

Over the past decades, strategies to cope with potentially harmful content online have adopted multiple regulatory forms. A number of states have enacted legal instruments aligned with the UN Convention on the Rights of the Child (1989) ${ }^{4}$ to protect the rights of children online. In the EU, for example, the European Agenda for the Rights of the Child 2011-2014 includes pathways to protect children in the digital world (European Commission, 2011). In the US, bills such as the Children's Online Privacy Protection Act of 1998 (COPPA) contain provisions to protect children from personal data collection and harmful online content.

Legal instruments usually come with information and education programmes on how to stay safe online. In Europe, the EU Commission has funded two networks, Insafe and Inhope, which

\footnotetext{
${ }^{4}$ http://www.ohchr.org/en/professionalinterest/pages/crc.aspx
} 
have set national awareness centres and helplines to launch campaigns, coordinate actions, and respond to questions regarding harmful or illegal online contents. ${ }^{5}$ Likewise, the programme KeepControl $^{6}$ targets online bullying and provides information at the state level on how to proceed when getting upsetting messages. In Australia, the Australian Communications and Media Authority (ACMA) runs Cybersmart, a programme providing information and facilitating online help and reporting to children and their families. ${ }^{7}$

In addition, and to a certain extent, legislation is gradually encouraging stakeholders to adopt self-regulation instruments. In the US, the Children's Online Privacy Protection Act (COPPA) enables industry groups or others to submit to the Federal Trade Commission (FTC) a "safe harbor application" with self-regulatory guidelines that implement the protections of the FTC. ${ }^{8}$ In the EU, up to 20 providers of social networking services (SNS) developed the Safer Social Networking Principles in consultation with the EU, which contains good practice recommendations for SNSs. ${ }^{9}$ Likewise, in 2012 and within the framework of 'A European Strategy for a Better Internet for Children', 31 leading companies across the audiovisual value chain signed up to a Coalition to develop, through a self-regulatory process, appropriate measures for: (i) simple and robust reporting tools for users; (ii) age-appropriate privacy settings; (iii) wider use of content classification; (iv) wider availability and use of parental control; and (v) effective removal of child abuse material.

The videogame industry is undergoing similar changes. In Europe, the Pan European Game Information System $(P E G I)^{10}$ is the self-regulation instrument developed by the Interactive Software Federation of Europe in 2003. The PEGI system is used in the majority of the EU Member States and includes an age rating system and a classification of content descriptors of a game to guide European consumers. Other widely used self-regulatory ratings and labels used by the videogame industry have been developed by the Entertainment Software Rating Board (ESRB). ${ }^{11}$

\subsection{Technology tools}

Technical systems such as parental controls, filtering, or age verification systems are available to families when it comes to select and/or monitor online contents. In his broad review of tools, Thierer defines parental controls as "any tool or method that parents, guardians or schools might use to restrict or tailor the media content that children consume" (2009, p. 14). The 2011 Report of the European Commission on Protecting Children in the Digital World ${ }^{12}$ highlights that $^{2}$

\footnotetext{
${ }^{5}$ http://www.saferinternet.org

6 http://www.keepcontrol.eu

7 http://www.cybersmart.gov.au

8 http://www.ftc.gov/safe-harbor-program

9 http://ec.europa.eu/digital-agenda/sites/digital-agenda/files/sn_principles.pdf

${ }^{10}$ http://www.pegi.info/en/index/

11 http:"www.esrb.org

12 (COM (2011) 556 final)

http://eur-lex.europa.eu/legal-content/EN/TXT/PDF/?uri=CELEX:52011DC0556\&from=EN
} 
the most common techniques used by parents to signal and restrict harmful content are preview on-screen icons and acoustic warnings. These techniques have generally been applied to television broadcast and on-demand audiovisual media services. Other technical filtering devices and software, including pre-locking systems and pin codes, are less popular.

Yet, as the 2011 EC Report alerts, "the solutions developed for linear/TV broadcasting (e.g. transmission times) often seem ill-adapted to Internet and other on-demand audiovisual media services". Similarly, a number of studies conclude that the mere use of certain software tools to block or remove unlawful or harmful content is not sufficient to prevent risks from the use of ICT by minors (Griffiths, 2000; Wolak et al., 2003; Fleming, 2006). In addition, further research argues that the prohibition or restriction of ICT technologies does not reduce risks regarding their use (McAlinden, 2006; Mitchell et al., 2007, 2008; Ybarra et al., 2008; Wolak et al., 2008). As Thierer puts it, "the best answer to the problem of unwanted media exposure or contact with others is for parents to rely on a mix of technological controls, informal household media rules, and, most importantly, education and media literacy efforts (2009, p. 16).

These findings coincide with the attitudes of parents interviewed for the pan-European survey. The parents "prefer far more to talk about internet safety than use parental controls in all countries and for all age groups", even if "the levels of parental mediation are not increasing despite parental concern and awareness-raising efforts" (Livingstone et al., 2014, p. 2).

\subsection{Co-regulatory instruments}

Co-regulatory instruments have proliferated in the last few years to take a horizontal, ad-hoc, and granular approach to manage the exposure, consumption, and use of digital media contents. Within families, they may adopt the form of family agreements; media time pledges, cell phone contracts, Facebook contracts, etc. Models and templates-freely available on the Internet - are typically drafted in plain language to facilitate discussion and agreement among all family members. In contrast with both legislation and soft law, where concepts such as "harmful", "illegal", "protection" or "vulnerability" are pervasive, family contracts are based on the principle of co-responsibility in establishing media uses and boundaries.

Fig. 1: Example of Family Media Agreement (source: Melbourne Montessori School)

Family contracts and agreements enable a proactive, co-responsible approach to deal with digital media uses and limits at the household level. The MediaKids project takes this paradigm a step further by empowering families, and especially children and young adults, to handle complaints involving exposure to harmful and/or illegal digital media contents.

\section{The MediaKids approach}


In Catalonia, a number of public and private organisations are entitled to handle complaints, suggestions, or inquiries about digital media contents. The Catalan Audiovisual Council (CAC), the official regulatory body, handles input from media users via phone call, e-mail, or by filling in an online form. In 2012, the CAC received 244 communications, of which 137 were inquiries and 107 complaints (17.8 per cent related to the protection of children and teenagers) (CAC 2013). Likewise, the Catalan Corporation of Audiovisual Media (CCMA), owner of TV and radio public broadcasting services, can handle complaints via its Customer Support Service and the Audience Ombudsman. Moreover, citizens can submit complaints via several phone?lines established by not-for-profit organisations and networks, such as the Protégeles [Protect them] hotline. ${ }^{13}$ However, these multiple outlets create some confusion about who is to handle what and the procedures to follow. In addition, our research has found that no evidentiary documents can be attached to the currently available online complaint forms.

The UAB Institute of Law and Technology started the MediaKids research project in 2012 in collaboration the Catalan Audiovisual Council-the independent body regulating audiovisual communication in Catalonia-and the European Observatory on Children's Television (OETI), an independent non-profit entity that works towards ensuring that children's television programmes and audiovisual material in general are educational, formative, and entertaining.

The MediaKids project had two cascading objectives dealing with harmful and illegal digital content in a converging digital world. First, extended ethnographic fieldwork was undertaken to elicit: (i) the perceptions of children and young adults with regard to harmful and illegal digital contents; (ii) the strategies and practices they usually adopt when dealing with these contents; (iii) the risky situations considered by minors in relation to consumption, production and the distribution of digital content; (iv) the parental norms that regulate access to this typology of content; and (v) the attitudes of minors towards reporting harmful/illegal content. Second, with the aim to promote a critical attitude in minors on the production, consumption and distribution of digital content, the research team developed a mobile app (MediaKids) to provide them and their families with a tool to encourage their proactive role in their own protection.

\section{Methodology}

The MediaKids project adopted a socio-legal perspective that combined both quantitative and qualitative research methods and integrated the views of minors from its very inception. The research was organised as a two-step process. First, researchers collected data on attitudes towards digital media content from an initial student survey (aged 9-17 years old) from three High Schools in the Barcelona area: Institut Jaume Balmes (279 students), Escola Ramon Fuster (235 students), and Institut Damià Campeny (426 students). To collect more nuanced data, researchers organised six focus groups (ten students each, two per centre) to discuss the minors' attitudes towards parental rules regulating access to digital content, views on harmful/illegal content, avoidance strategies, and the needs for reporting harmful/illegal content.

\footnotetext{
${ }^{13}$ http://www.protegeles.com/index.asp
} 
In a second step, and stemming from the results of the survey and the focus groups, three training sessions were held at the three centres (approximately 45 minutes each). Theeducational sessions were organised in conjunction with the European Observatory on Children's TV. Relying on participatory observation, the research team used multimedia tools to estimulate the discussion on strategies to cope with potentially harmful content and presented a video-tour of the MediaKids prototype app to collect feedback from minors about its aim and functionalities. Both the training sessions and the focus groups were videotaped with the explicit consent of all participants and their parents.

The ultimate goal of the research was to produce a set of audiovisual materials that help to understand how risk situations are perceived and to identify the mechanisms that minors apply in conflictive situations as they deal with potentially harmful or illegal content. Researchers thought that these sources could then inform the outputs of self-regulation processes, namely guidelines, codes of conduct, or recommendations produced by relevant stakeholders such as broadcasters, ICT providers, social networks, regulatory media authorities, data protection authorities, ONGs, and law enforcement agencies.

As a result of minors' feedback, researchers tweaked the original planning so that the properties of their relationships with mobiles could be better understood. The ethnographic approach provided an insight into the many strategies used by children and teenagers to browse the web, upload pictures, connect to their friends, and do their own queries. In this particular context, "harm" is pragmatically perceived in relation to the construction of their digital identity, and mainly through the layout of mobile devices. Researchers found that children seemed to be more concerned with privacy and intimacy than with potential harm, because they established a personal and self-reflexive relationship within the digital ecosystem they build up through the web. Therefore, they praised both to be connected and to be let alone at the same time.

The research revealed that the things minors most valued were: (i) not losing control over the content: (e.g. "... I was annoyed by the image of a smashed cat... so I closed the picture" (secondary school student, third year); "... if something pops up that I don't like, I just minimise it' (secondary school student, second year); (ii) staying tuned, not losing contact with friends and social networks: "... I would tell my friends, they are my peers, we trust each other" (secondary school student, first year); (iii) not being bound to speak to their parents "...l don't know how to file a complaint, or to whom, I don't know anything about that, but I would never tell my parents unless it was something really serious" (secondary school student, fourth year); (iv) not being bound to know in advance how to fill a complaint and to whom: "...if the tool knows how to handle it, that would be great, we have no idea, well, yeah, I know you can complain on Face, there is a way to do it..."(secondary school student, third year); ( $v$ ) not being bound to discriminate by themselves illegal from legal content: "...that would be great but the problem is that I don't know what is legal and what is not, or if a 1-minute ad is allowed" (secondary school student, second year); (vi) not being bound to learn how to make use of the system: “... if it was easy and wouldn't take much time to complain"(secondary school student, fourth year); (vii) not 
being bound to get out of their own routines to learn about acceptable or harmful content : “... I learn the rules by watching videos, problems someone else has had and the like" (secondary school student, second year).

\section{How the MediaKids app has been developed}

MediaKids is a user-friendly reporting tool jointly designed in several iterations by legal sociologists and app developers from the UAB Institute of Law and Technology. To facilitate the reporting process, the MediaKids mobile application operates as a single entry point to channel the submission of complaints, opinions and suggestions and forward them to the competent agencies. Fig. 2 depicts the design strategy for the application, based on the specific regulatory knowledge and protection strategies elicited from children's own statements.

Fig. 2: MediaKids conceptual design

With MediaKids, users can submit their input on any radio or TV show, ad, movie, website, forum, video game etc. from any source or broadcasting service. The MediaKids app then tags the user input with a set of pre-defined categories and forwards it to the competent entity (service provider, regulatory body or legal enforcement agency). Initially, the app has been designed for the Catalan audiovisual domain, but it can be escalated to the Spanish and European domains. MediaKids is currently available for Android and iOS, which have a combined share of 90 per cent of the smartphone market in Spain.

From a users' perspective, MediaKids consists of a short questionnaire aimed at determining key data such as the type of content reported (TV show, ad, videogame forum, etc.) and its source (TV, radio, Internet, videogame, etc.). This input data is then used to automatically categorise the report and redirect it to the competent institution or regulatory agency. Users can enrich their reports by providing GPS coordinates, screenshots, images, or recorded sounds and voices. The MediaKids architecture is intentionally lightweight in order to streamline the reporting process. The flow chart below represents the underlying architecture.

Fig. 3: Initial architecture of the MediaKids app

The different iterations of the architecture were tested with experts at the Catalan Audiovisual Council and the European Observatory on Children's Television, who provided feedback on the functionalities and on the type of complaints the application should be able to handle. In this regard, Council experts provided researchers with a comprehensive list of potential issues 
drawn from both Catalan legislation and their own expertise in handling complaints. These cases were eventually included in the latter versions of the application. The regulatory organisations that helped with the design process were now able to channel complains in a highly structured format.

Fig. 4: Decision tree for the content "show"

The MediaKids' backend has a decision tree for each issue it can handle. The application launches a questionnaire to help the user to find the competent authority and file a complaint or a suggestion with all the required data. The lists of potential complaints were jointly elaborated with the competent authorities. Below is an example of the list discussed with the Catalan Audiovisual Council.

Table 1: Complaints list by the Catalan Audiovisual Council

The final stage in the design process is the front-end of the application. The user can complete the questionnaire in a few screens and, if available, attach any additional information (picture, screenshot, etc.) to complete the reporting process. The main advantage is that the user can be agnostic about the competent authority that will eventually handle the request.

Fig. 5: Screenshots of the MediaKids mobile application

\section{Conclusions and future work}

Technology has historically played a central role in supporting family connections (Neustaedter et al., 2012). The convergence of mobile technologies, media and the Internet is transforming the way digital content is produced, distributed, and consumed, especially among children and young adults. Exposure to digital media comes with both new opportunities and risks that can be addressed with different approaches, actions and tools. Children do not conceive mobile technologies as a separate entity, rather they consider them as natural components in a wide variety of media (Bond, 2014). It has been recently suggested that children and young people use social media to take care of themselves, engaging in a kind of "economy of dignity" (Wilson, 2015). Thus, mobile technologies have become a part of their identity, and they are being integrated into classrooms (Herro et al., 2014) and families - particularly the families of children with special needs (Meder and Wegner, 2015). Mobile scenarios in these emergent educational and family ecosystems are far from simple, and so are the ways of regulating and monitoring them.

This paper has reviewed different strategies involving self-regulation and co-regulation to facilitate meaningful, harmless consumption of digital media. Some initiatives also include 
coordinated actions at the national and international level and cooperation between different stakeholders, including education institutions and regulatory bodies, to foster children's media literacy. In Catalonia, the ethnographic fieldwork found that, in spite of the dense institutional guidance for online children protection, complaints about an ever-growing number of multimedia sources remained relatively low. The reasons for this are manyfold: (i) the current dispersion of procedures across various regulatory agencies, non-profit organisations, police forces, and other public and private entities; (ii) procedures not fully adapted to users' needs (for instance, evidentiary documents cannot be attached to online complaint forms); (iii) the trend to leave online protection of minors almost exclusively to parental control.

Taking this background into account, our research developed MediaKids, a mobile application that enables children and young adults to report inappropriate or potentially harmful content via comments, opinions, suggestions, claims and complaints. From this perspective, the MediaKids app can be primarily conceived as an intermediating service that creates its own social ecosystem as it requires the cooperation of the school community (peers and teachers) and the family to produce both educational and socialisation effects. MediaKids service is therefore linked to a bottom-up strategy that encourages minors, families, school peers and teachers to take an active role in: (i) defining (and re-defining) situations of exposure to digital media contents that are perceived as risky; (ii) adopting a critical attitude towards how digital content is produced, consumed, shared, etc.; (iii) shaping future regulatory models to efficiently tackle both opportunities and risks.

Future work on the MediaKids project includes an evaluation of the impact of both the educational sessions at secondary schools and the deployment of the mobile app. A survey will be carried out at the end of the project among the same pupils to gather their feedback on their perceptions about the training and awareness-raising initial sessions and the use of the mobile app. The same issues will be analysed in three-different focus groups at each school. The goal is to detect and track behavioural changes (if produced) concerning the minors' attitudes towards dealing with harmful or illegal digital content.

A digital world may entail new risks to child safety, but it can also facilitate new synergies to protect them in a non-paternalistic way. Enhancing their own identities and creating their active roles is a better strategy than merely raising external barriers against potential dangers. As the response to major emergencies and disasters has been showing in the past few years (Poblet et al. 2014) intermediating technologies (such as crowdsourcing or microtasking) are fostering new forms of active citizenship. The new technology-enabled "digital neighbours" are constantly monitoring social media, collecting data, curating information, mapping events, etc. Digital neighbours create communities of interest around a growing number of domains: disaster management, political participation, science and research, education and learning, etc. They are granular and self-selective in their "interests", but "global" when it comes to reach. 
The future regulatory models to ensure online safety for children and young adults will need to embed the local, the granular, and the global dimensions if they aspire to be adaptive, efficient, and inclusive. But, above all, they will need to embed the way children and young adults are already taking care of themselves. Digital awareness and the digital neighbourhood are two sides of the same coin. In our perspective, children and young people should be considered as active players in the construction of policies for this this new, emergent public space. The "handheld" approach to online safety proposed in this paper requires a merger between a local, bottom-up strategy with coordination mechanisms to facilitate the participation of civil society sat different levels, including the global one.

\section{Acknowledgements}

This work has been funded by the grant "MediaKids: An Online Application to Protect Kids from Harmful Digital Contents" (Obra Social La Caixa, RecerCaixa2012), and partially by the grant "Crowdsourcing: semantic tools to develop participation and mediation online" (Spanish Ministry of Economy and Competitiveness, DER2012-39492-C02-01). Special thanks go to pedagogical coordinators Albert Davi (I.E.S Balmes, Barcelona), Ramon Bosch (I.E.S Damià Campeny, Mataró), Hug Llàcer and Marc Fontanet (Escola Ramon Fuster, Bellaterra) for their ongoing support and colaboration.

\section{References}

Bell, V., Bishop, D.V.M, \& Przybylsk, A.K. (2015). The debate over digital technology and young people. BMJ. doi: 10.1136/bmj.h3064. Retrieved from

http://press.psprings.co.uk/bmj/august/technology.pdf

Bond, E. (2014). Childhood, mobile technologies and everyday experiences: changing technologies $=$ changing childhoods?. Hampshire, UK: Palgrave Macmillan.

Bonnici, J.P.M., \& De Vey Mestdagh, C.N.J. (2005). Right Vision, Wrong Expectations: The European Union and Self-regulation of Harmful Internet Content. Information \& Communications Technology Law, 14(2), 133-149.

Canovas, G., García de Pablo, San Atilano, A., \& Aboy Ferrer, I. (2014). Menores de Edad y Conectividad Móvil en España: Tablets y Smartphones. Retrieved from

http://www.diainternetsegura.es/descargas/estudio_movil_smartphones_tablets_v2c.pdf

Casanovas, P. (2012). Legal crowdsourcing and relational law: what the semantic web can do for legal education. Journal of Australian Law Teachers Association 5, 1-17. Retrieved from http://ddd.uab.cat/pub/artpub/2012/116674/jouauslawtea_a2012v5n1-2p159iENG.pdf Casanovas, P., \& Poblet, M. (2008). Concepts and fields of relational justice. Lecture Notes in Computer Science, 4884, 323-339.

Castells, M., Fernandez-Ardevol, M., Sey, A., \& Qiu J. L. (2007). Mobile communication and society: A global perspective. Cambridge, MA: MIT Press. 
Chen, Y. F., \& Katz, J. E. (2009). Extending family to school life: College students' use of the mobile phone. International Journal of Human-Computer Studies, 67(2), 179-191.

Correa, T., Straubhaar, J. D., Chen, W., \& Spence, J. (2015). Brokering new technologies: The role of children in their parents' usage of the Internet. New Media \& Society 0(0), 1-18.

Retrieved from 10.1177/1461444813506975.

EU Digital Agenda. (2009). Safer Social Networking Principles for the EU. Retrieved from http://ec.europa.eu/digital-agenda/sites/digital-agenda/files/sn_principles.pdf

European Commission. (2011). An EU Agenda for the Rights of the Child. Retrieved from http://ec.europa.eu/justice/policies/children/docs/com_2011_60_en.pdf

European Commission. (2013). Green Paper on "Preparing for a Fully Converged Audiovisual

World: Growth, Creation and Values". Available at https://ec.europa.eu/digital-

agenda/sites/digital-agenda/files/convergence_green_paper_en_0.pdf

Fleming, M.J. (2006), Safety in cyberspace - adolescents' safety and exposure online, Youth Society, 38(2), 135-154.

Granic, I., Lobel, A., \& Engels, R.C. (2014). The benefits of playing video games. American Psychologist, 69(1), 66-78.

Green, L., Brady, D., Ólafsson, K., Hartley, J., \& Lumby, C. (2011). Risks and safety for Australian children on the internet: Full findings from the AU Kids Online survey of 9-16 year olds and their parents.

Green, L., Ólafsson, K., Brady, D., \& Šmahel, D. (2012). Excessive internet use among

Australian children. Retrieved from

http://www.cci.edu.au/sites/default/files/Excessive\%20internet\%20use\%20among\%20Australian \%20children\%20final_0.pdf.

Green, L., Brady, D., Holloway, D., Staksrud, E., \& Ólafsson, K. (2013). What bothers Australian kids online? Children comment on bullies, porn and violence. Retrieved from

http://www.cci.edu.au/reports/WhatBothersAusKidsFIN.pdf

Griffiths, M. (2000). Excessive Internet use: Implications for sexual behavior. CyberPsychology and Behavior, 3(4), 537-552.

GSMA. 2015. The mobile economy. Retrieved from

https://gsmaintelligence.com/research/?file=08bd184710b7e671e80cfe6693cead2d\&download Herro, D., Kiger, D., \& Owens, C. (2014). Mobile Technology. Case-Based Suggestions for Classroom Integration and Teacher Educators, Journal of Digital Learning in Teacher Education, 30(1), 30-40.

Hertlein, K. M. (2012). Digital dwelling: Technology in couple and family relationships. Family Relations, 61(3), 374-387.

Hirose, M., Beverly, E.A., \& Weinger, K. (2012). Quality of life and technology: impact on children and families with diabetes. Current Diabetes Reports, 12(6), 711-720. Retrieved from http://cultural-science.org/journal/index.php/culturalscience/article/view/49/129.

Hwang, I., Yoo, C., Hwang, C., Yim, D., Lee, Y., Min, C., ... \& Song, J. (2014, February).

TalkBetter: family-driven mobile intervention care for children with language delay. In Proceedings of the 17th ACM Conference on Computer Supported Cooperative Work and Social Computing, 1283-1296.

INE. (2014). España en cifras. Retrieved from http://www.ine.es/prodyser/espa_cifras/2014/files/assets/basic-html/page26.html 
Ito, M. (2005). Mobile phones, Japanese youth and the replacement of social contact. In R. Ling and P. Pedersen (eds.), Mobile communications: Renegotiation of the social sphere. London, UK: Springer, 131-148.

ITU. (2014). Facts and Figures. Retrieved from http://www.itu.int/en/ITU-

D/Statistics/Documents/facts/ICTFactsFigures2014-e.pdf

Jackson, L. A., Witt, E. A., Games, A. I., Fitzgerald, H. E., von Eye, A., \& Zhao, Y. (2012).

Information technology use and creativity: Findings from the Children and Technology Project. Computers in Human Behavior, 28(2), 370-376.

Kaare, B. H., Brandtzæg, P. B., Heim, J., \& Endestad, T. (2007). In the borderland between family orientation and peer culture: the use of communication technologies among Norwegian tweens. New Media \& Society, 9(4), 603-624.

Katz, J. E., \& Aakhus, M. (Eds.) (2002). Perpetual contact: Mobile communication, private talk, public performance. Cambridge University Press.

Kasesniemi, E-L. (2003). Mobile messages: Young people and a new communication culture.

Tampere: Tampere University Press.

Lievens, E. (2007). "Protecting Children in the New Media Environment: Rising to the

Regulatory Challenge?" Telematics and Informatics, 24(4), 315-30. Retrieved from doi:10.1016/j.tele.2007.01.005.

Light, J., \& McNaughton, D. (2012). Supporting the communication, language, and literacy development of children with complex communication needs: State of the science and future research priorities. Assistive Technology, 24(1), 34-44.

Ling R. (2004). The mobile connection: The cell phone's impact on society. San Francisco, CA: Morgan Kaufmann.

Ling, R. (2007). Children, youth, and mobile communication. Journal of Children and Media, 1(1), 60-67.

Ling R. (2008). New tech, new ties: How mobile communication is reshaping social cohesion. Cambridge, MA: MIT Press.

Livingstone, S., Mascheroni, G., Ólafsson, K., \& Haddon, L. (2014a). Children's online risks and opportunities: Comparative findings from EU Kids Online and Net Children Go Mobile. Retrieved from http://netchildrengomobile.eu/ncgm/wp-content/uploads/2014/11/EU-Kids-Online-Net-

Children-Go-Mobile-comparative-report.pdf

Livingstone, S., Haddon, L., Vincent, J., Mascheroni, G., \& Ólafsson, K. (2014b). Net children go mobile: the UK report: a comparative report with findings from the UK 2010 survey by EU Kids Online. Retrieved from

http://www.Ise.ac.uk/media@Ise/research/EUKidsOnline/EU\%20Kids\%20III/Reports/NCGMUKR eportfinal.pdf

Livingstone, S., Marsh, J., Plowman, L., Ottovordemgentschenfelde, S., \& Fletcher-Watson, B. (2015). Young children (0-8) and digital technology: A qualitative exploratory study - National report - UK. Retrieved from http://www.children-and-technology.ed.ac.uk/wp-content/uploads/2015/03/children_08 and_digital_technology_UK_report_2015.pdf 
Livingstone, S., Haddon, L., Görzig, A., \& Ólafsson, K. (2011). Risks and safety on the internet: the perspective of European children: full findings and policy implications from the EU Kids Online survey of 9-16 year olds and their parents in 25 countries Deliverable D4. EU Kids Online, London, UK. Retrieved from http://eprints.Ise.ac.uk/33731/. McAlinden, A.M. (2006). Setting 'em up': Personal, familial and institutional grooming in the sexual abuse of children. Social Legal Studies, 15(3): 339-362.

McPake, J., Plowman, L., \& Stephen, C. (2013). Pre-school children creating and communicating with digital technologies in the home. British Journal of Educational Technology, 44(3): 421-431.

Meder, Allison M. ; Wegner, Jane R. (2015). iPads, Mobile Technologies, and Communication Applications: A Survey of Family Wants, Needs, and Preferences, Augmentative and Alternative Communication, 31(1), 27-36.

Mitchell, K. J., Finkelhor, D., \& Wolak, J. (2007). Youth Internet users at risk for the most serious online sexual solicitations, American Journal of Preventive Medicine, 32(6): 532-537.

Mitchell, K. J., Wolak, J., \& Finkelhor, D. (2008). Are blogs putting youth at risk for online sexual solicitation or harassment? Child Abuse \& Neglect, 32(2): 277-294.

Mosnaim, G. S., Powell, L. H., \& Rathkopf, M. (2012). A review of published studies using interactive Internet tools or mobile devices to improve asthma knowledge or health outcomes. Pediatric Allergy, Immunology, and Pulmonology, 25(2): 55-63.

Neustaedter, C., Harrison, S., \& Sellen, A. (Eds.). (2012). Connecting Families. The Impact of New Communication Technologies on Domestic Life. Dordrecht, Heidelberg, New York:

Springer-Verlag.

Oksman, V., \& Rautiainen, P. (2003). Perhaps it is a body part: How the mobile phone became an organic part of the everyday lives of Finnish children and teenagers. In J. E. Katz (ed.) Machines that become us: The social context of personal communication technology. New Brunswick, Transaction Publishers,161-70.

Padilla-Walker, L. M., Coyne, S. M., \& Fraser, A. M. (2012). Getting a High-Speed Family Connection: Associations between Family Media Use and Family Connection. Family Relations, 61(3): 426-440.

Palmer, S. B., Wehmeyer, M. L., Davies, D. K., \& Stock, S. E. (2012). Family members' reports of the technology use of family members with intellectual and developmental disabilities. Journal of Intellectual Disability Research, 56(4): 402-414.

Pew Research. (2013). Teens, social media, and privacy. Retrieved from http://www.pewinternet.org/2013/05/21/part-1-teens-and-social-media-use/

Plowman, L., \& McPake, J. (2013). Seven myths about young children and technology. Childhood Education, 89(1): 27-33.

Plowman, L., McPake, J., \& Stephen, C. (2010). The technologisation of childhood? Young children and technology in the home. Children \& Society, 24(1): 63-74.

Plowman, L., Stevenson, O., Stephen, C., \& McPake, J. (2012). Preschool children's learning with technology at home. Computers \& Education, 59(1), 30-37.

Poblet, M. (ed.). (2011). Mobile Technologies for Conflict Management: Online Dispute Resolution, Governance, Participation. Berlin: Springer-Verlag. 
Poblet, M. 2013. Visualizing the law: Crisis mapping as an open tool for legal practice. Journal of Open Access to Law, 1(1), 1-20. Retrieved from

http://ojs.law.cornell.edu/index.php/joal/article/viewFile/12/13

Poblet, M., Garcia-Cuesta, E., \& Casanovas, P. (2014). Crowdsourcing Tools for Disaster

Management: A Review of Platforms and Methods. Lecture Notes in Artificial Intelligence, 8929, 261-274.

Rideout, V. (2014). Learning at home: Families' educational media use in America. New York: Joan Ganz Cooney Center. Retrieved from http://www.joanganzcooneycenter.org/wpcontent/uploads/2014/01/jgcc_learningathome.pdf.

Rizza, C., \& Guimaraes Prereira, A. (2013). Social Networks and Cyber-bullying among Teenagers. JRC Scientific and Policy Reports. Retrieved from

https://ec.europa.eu/jrc/sites/default/files/lbna25881enn.pdf

Selwyn, N. (2003). Schooling the mobile generation: The future for schools in the mobilenetworked society. British Journal of Sociology of Education, 24(2), 131-144.

Shapiro, L. A. S., \& Margolin, G. (2014). Growing up wired: Social networking sites and adolescent psychosocial development. Clinical child and family psychology review, 17(1), 1-18. Retrieved from http://www.ncbi.nlm.nih.gov/pubmed/23645343

Sharifi, M., Dryden, E. M., Horan, C. M., Price, S., Marshall, R., Hacker, K., Taveras, \& E. M. (2013). Leveraging text messaging and mobile technology to support paediatric obesity-related behavior change: a qualitative study using parent focus groups and interviews. Journal of medical Internet research, 15(12). Retrieved from

http://www.ncbi.nlm.nih.gov/pmc/articles/PMC3869083/

Shuler, C. (2009). Pockets of potential: Using mobile technologies to promote children's learning. New York, NY: The Joan Ganz Cooney Center at Sesame Workshop.

Strasburger, V. C., Hogan, M. J., Mulligan, D. A., Ameenuddin, N., Christakis, D. A., Cross, C., \& Swanson, W. S. L. (2013). Children, adolescents, and the media. Pediatrics, 132(5), 958-961. Thierer, A. (2009). Parental controls and Online Child Protection: A Survey of Tools \& Methods. Retrieved from

http://www.pff.org/parentalcontrols/Parental\%20Controls $\% 20 \& \% 200$ nline $\% 20$ Child $\% 20$ Protecti on\%20[VERSION\%204.0].pdf

Toscos, T. R., Ponder, S. W., Anderson, B. J., Davidson, M. B., Lee, M. L., MontemayorGonzalez, E., \& McMahon, K. L. (2012). Integrating an Automated Diabetes Management System Into the Family Management of Children With Type 1 Diabetes Results from a 12-month randomized controlled technology trial. Diabetes care, 35(3), 498-502.

Vincent, J. (2015). Mobile opportunities: exploring positive mobile opportunities for European children. POLIS, The London School of Economics and Political Science, London, UK.

Retrieved from

http://eprints.Ise.ac.uk/61015/1/_Ise.ac.uk_storage_LIBRARY_Secondary_libfile_shared_repos itory_Content_POLIS_Vincent_Mobile-Opportunities_2015.pdf.

Williams, S., \& Williams, L. (2005). Space invaders: The negotiation of teenage boundaries

through the mobile phone. The Sociological Review, 53(2), 314-331.

Wilson, S. (2015, April 2). Digital technologies, children and young people's relationships and self-care. Children Geographies. Retrieved from http://dx.doi.org/10.1080/14733285.2015.1040726. 
Wolak, J., Finkelhor, D., Mitchell, K. J., \& Ybarra, M. L. (2008). Online "predators" and their victims: Myths, realities, and implications for prevention and treatment. American Psychologist, 63(2), 111-128.

Wolak, J., Mitchell, K. J., \& Finkelhor, D. (2003). Escaping or connecting? Characteristics of youth who form close online relationships. Journal of Adolescence, 26(1), 105-119.

Woolford S. J., Barr K. L., Derry H. A., Jepson C. M., Clark S. J., Strecher, V.J., \& Resnicow K. (2011). OMG do not say LOL: obese adolescents' perspectives on the content of text messages to enhance weight loss efforts. Obesity, Vol. 19(12), 2382-2387. Retrieved from

http://www.ncbi.nlm.nih.gov/pubmed/21869762.

Ybarra, M. L., \& Mitchell, K. J. (2008). How risky are social networking sites? A comparison of places online where youth sexual solicitation and harassment occurs. Pediatrics, 121(2).

Retrieved from http://pediatrics.aappublications.org/content/121/2/e350. 


\section{Tables}

\begin{tabular}{|l|}
\hline \multicolumn{1}{|c|}{ Complaints list CAC } \\
\hline Discriminatory contents \\
\hline Violent contents \\
\hline Inappropriate behaviour \\
\hline Obscene language \\
\hline Violation of "family hour" time \\
\hline Dangerous behaviours \\
\hline Presence of drugs \\
\hline Sexual/pornographic contents \\
\hline Gambling \\
\hline Broadcasting language \\
\hline Lack of pluralism \\
\hline Lack of information fairness \\
\hline Programming change with no previous notice \\
\hline Contents inappropriately rated \\
\hline Excess of advertisements \\
\hline
\end{tabular}

Table 1: Complaints list by the Catalan Audiovisual Council 


\section{List of figures}

Fig. 1: Example of Family Media Agreement (source: Melbourne Montessori School)

Fig. 2: MediaKids conceptual design

Fig. 3: Initial architecture of the MediaKids app

Fig. 4: Decision tree for the content "show"

Fig. 5: Screenshots of the MediaKids mobile application 